\title{
Inflammation, Autoimmunity and Exacerbations: A Promising Area for New Studies in COPD
}

\author{
Thyego Mychell Moreira Santos*
}

Faculty of Medicine of Botucatu, Saulo State University-UNESP, Brazil

*Corresponding author: Moreira Santos TM, Faculty of Medicine of Botucatu, São Paulo State University-UNESP, Brazil, Tel: +55 14 3880-1001; Email: thymy25@hotmail.com

Received date: February 02, 2018; Accepted date: February 26, 2018; Published date: March 05, 2018

Citation: Moreira Santos TM (2018) Inflammation, Autoimmunity and Exacerbations: A Promising Area for New Studies in COPD. Chron Obstruct Pulmon Dis Vol No. 3 Iss No. 1: 30.

Copyright: (c) 2018 Moreira Santos TM. This is an open-access article distributed under the terms of the Creative Commons Attribution License, which permits unrestricted use, distribution, and reproduction in any medium, provided the original author and source are credited.

\section{Abstract}

Chronic obstructive pulmonary disease (COPD) is an inflammatory airway disease whose incidence and mortality increases every year. COPD is characterized by irreversible airflow limitation based on obstructive bronchiolitis and emphysema. It is associated with an abnormal inflammatory response of the lung to toxic particles or gases, such as cigarette smoke. Recently, an increasing body of evidence has been accumulated for a link between inflammation and autoimmunity in the development of COPD. The idea that autoimmunity could contribute to the development of COPD provides a new angle to understand the pathogenesis of the disease. However, the non-physiological stress caused by environmental factors such as cigarette smoking is linked to the inflammatory process and autoimmunity, and all these factors may contribute to the occurrence of exacerbation in COPD. It will be demonstrated some evidences that support this paradigm and the need to invest in research in this area.

\section{Introduction}

Chronic Obstructive Pulmonary Disease (COPD) is a chronic, irreversible and debilitating disease, characterized by persistent airflow limitation that is usually progressive and caused by an increased inflammatory response in the airways and the lung to noxious particles or gases. COPD is a major cause of morbidity and mortality worldwide, affecting millions of people every year. The major risk factor for COPD is smoking. However, additional risk factors include genetic predisposition, exposure to secondhand smoke, chemicals, air pollution, heredity and history of childhood respiratory infections [1]

COPD affects more than 5 percent of the population and is associated with high morbidity and mortality [2]. It is the third leading cause of death in the world today [3], killing more than 120,000 individuals each year [4]. More than 3 million people died of COPD in 2012 [1]. In the U.S., COPD results in 15.4 million physician visits, 1.5 million emergency department visits, and 726,000 hospitalizations each year [5].
Globally, the COPD burden is projected to increase in coming decades because of continued exposure to COPD risk factors and aging of the population [1] and the COPD load is designed to increase in coming decades because of continued exposure to COPD risk factors, especially regarding the use of cigarettes, and aging of the population [6].

COPD has as a consequence high prevalence and chronicity; it causes high use of resources with frequent visits to the clinic, frequent hospitalizations due to acute exacerbations, and requiring greater demand for oxygen therapy and medication [7], which demands a greater economic cost for the health sector.

Exacerbations of COPD are episodes of worsening of symptoms, are associated with increased airway and systemic inflammation. They are triggered mainly by bacteria and viruses, which infect the airway and increase airway inflammation $[8,9]$. Exacerbations associated with infections occur mainly due to a defective response of the immune system in patients with COPD, being aggravated more by the use of the cigarette [10]. Although circumstantial results of a role for autoimmunity in patients with COPD caused by cigarette use have been identified, there is growing evidence that both cellular and antibody-mediated autoimmunity also has an important role in the progression of COPD.

\section{Inflammation and autoimmunity a possible link with the heat shock protein (HSP)}

According to all the evidences found in important studies, observes a great highlight for two fundamental mechanisms for the occurrence of exacerbations in COPD, inflammation and autoimmunity. COPD is responsible for persistent airflow limitation that is usually progressive and caused by an increased inflammatory response in the airways [1]. inflammatory mediators, such as TNF- $\alpha$, IFN- - , IL- 8 , lipid mediators, reactive oxygen and nitrogen species, are involved in airway inflammation in COPD $[12,13]$ being responsible for inducing parenchymal destruction and consequently small airway fibrosis, leading to dyspnea and limitation of physical activity [14].

The disease paradigm suggests that an imbalance of the inflammatory process versus action of the immune system in the 
lungs can trigger an autoimmune response, leading to destruction of lung tissue. In the last years, growing evidence indicates that patients with COPD exhibit characteristics of a classical autoimmune response $[15,16]$. Recent evidence has also suggested that an inflammatory response is characterized by antibodies directed against the pulmonary epithelium and lung matrix [11].

In particular, the proteins modified by non-physiological stress may help to stimulate the development of COPD and cause airways abnormalities and even contribute to the pathogenesis of pulmonary emphysema [17]. Although direct, indirect, and circumstantial evidence of a role for autoimmunity in stable patients with COPD has been identified [18], no relationship between HSPs and autoimmunity in patients with COPD was found.

Literature shows that the alteration of the immune system is responsible for the phenomenon of autoimmunity in patients with COPD and indirectly the HSPs protein could be involved in this mechanism. according to the Cherneva et al., the immune system is involved, but instead of restoring the balance it augments the oxidative stress, generating a large number of reactive - oxygen species. This leads to the accumulation of modified selfproteins that are recognized as antigenic. Autoimmunity occurs as an epiphenomenon. A vicious circle is created. The environmental and the inflammatory oxidative stress lead to the accumulation of modified proteins [19].

Scientific evidence shows that a protein stands out in relation to the pathophysiology of COPD [20] there is an important relationship between this protein and the inflammatory [21,22] and autoimmune process [23]. Heat shock protein 70 (HSP70), is ubiquitous and highly conserved proteins whose expression is induced in response to non-physiological stress such as smoking $[24,25]$.

Recently our team discovered that chronic asymptomatic smokers have high level of this protein in the blood, as well as increased autoantibodies against this protein (data in process of publication). We suggest that the two proteins may form circulating immune complexes, increasing the inflammatory process and stimulating cells of the immune system with neutrophils to synthesize mediators deleterious to the lung tissue. We believe that this process also occurs in patients with COPD, which favors the occurrence of exacerbations.

Considering all this line of thought, the evidence found in the literature suggest that the infections and alteration of the immune system response caused by cigarette smoking may help to drive autoimmunity in COPD, contributing to the pathogenesis of pulmonary emphysema. These factors can be triggered by increased non-physiological stress with changes in the action of some proteins such as HSPs, which is linked to the inflammatory process and the possibility of developing an autoimmune response.

Indeed, new studies need to be invested in this area, seeking to clarify the role of heat shock proteins in the involvement of inflammation, autoimmunity and exacerbations. If confirmed the deleterious role of this protein linked to the exacerbations of the disease, new clinical studies may investigate the action of
HSP70 inhibitors during this critical period. However, these studies should be extremely controlled, due to the protective function of this protein inside the cell, so that there are no adverse events that affect more the health of the patients.

\section{References}

1. Global Initiative for Chronic Obstructive Lung Disease (2018) Pocket Guide to COPD Diagnosis, Management, and Prevention. A Guide for Health Care Professionais 2018 edition.

2. Centers for Disease Control and Prevention (CDC) (2012) Chronic Obstructive Pulmonary Disease among Adults--United States, 2011. MMWR Morb Mortal Wkly Rep 61: 938-943.

3. Decramer M, Janssens W, Miravitlles M (2012) Chronic Obstructive Pulmonary Disease. Lancet 379: 1341-1351.

4. Miniño AM, Murphy SL, Xu J, Kochanak KD (2011) Deaths: Final Data for 2008. Natl Vital Stat Rep 59: 1-126.

5. Mannino DM, Homa DM, Akinbami LJ, Ford ES, Redd SC (2002) Chronic Obstructive Pulmonary Disease Surveillance-United States, 1971-2000. MMWR Surveill Summ 51: 1-16.

6. Mathers CD, Loncar D (2006) Projections of Global Mortality and Burden of Disease From 2002 to 2030. PLoS Med 3: e442.

7. Buist AS, McBurnie MA, Vollmer WM, Gillespie S, Burney $P$, et al. (2007) International Variation in the Prevalence of COPD (the BOLD Study): A Population-Based Prevalence Study. Lancet 370: 741-750.

8. Wedzicha JA, Seemungal TA (2007). COPD Exacerbations: Defining their Cause And Prevention. Lancet 370: 786-796.

9. Mador MJ, Sethi S (2013) Systemic Inflammation in Predicting COPD Exacerbations. JAMA 309: 2390-2391.

10. Nurwidya F, Damayanti T, Yunus F (2016) The Role of Innate and Adaptive Immune Cells in the Immunopathogenesis of Chronic Obstructive Pulmonary Disease. Tuberc Respir Dis (Seoul) 79: 5-13.

11. Jiang $Y$, Wang $X$, Hu D (2017) Mitochondrial Alterations During Oxidative Stress in Chronic Obstructive Pulmonary Disease. Int J Chron Obstruct Pulmon Dis 12: 1153-1162.

12. Singh S, Verma SK, Kumar S, Ahmad MK, Nischal A, et al. (2018) Correlation of Severity of Chronic Obstructive Pulmonary Disease with Potential Biomarkers. Immunol Lett 196: 1-10.

13. Austin V, Crack PJ, Bozinovski S, Miller AA, Vlahos R (2016) COPD and Stroke: Are Systemic Inflammation and Oxidative Stress the Missing Links? Clin Sci (Lond) 130: 1039-1050.

14. Wen L, Krauss-Etschmann S, Petersen F, Yu X (2018) Autoantibodies in Chronic Obstructive Pulmonary Disease. Front Immuno 19: 66.

15. Stefanska AM, Walsh PT (2009) Chronic Obstructive Pulmonary Disease: Evidence for an Autoimmune Component. Cell Mol Immuno 16: 81-86.

16. Núñez B, Sauleda J, Antó JM, Julià MR, Orozco M et al., (2011) PAC-COPD Investigators. Anti-tissue Antibodies are Related to Lung Function in Chronic Obstructive Pulmonary Disease. Am J Respir Crit Care Med 183: 1025-1031.

17. Ünver R, Deveci F, Kırkıl G, Telo S, Kaman D , et al., (2016) Serum Heat Shock Protein Levels and the Relationship of Heat Shock Proteins with Various Parameters in Chronic Obstructive Pulmonary Disease Patients. Turk Thorac J 17: 153-159. 
18. Caramori G, Ruggeri P, Di Stefano A, Mumby S, Girbino G et al., (2017) Autoimmunity and COPD: Clinical Implications. Chest 1-8.

19. Cherneva R, Petrova D, Georgiev O (2012) Chronic Obstructive Pulmonary Disease - Chaperonopathology. Chronic Obstructive Pulmonary Disease - Current Concepts and Practice. Book edited by Kian-Chung Ong, ISBN 978-953-51-0163-5. Available from: https://www.intechopen.com/books/chronic-obstructivepulmonary-disease-current-concepts-and-practice/chronicobstructive-pulmonary-disease-chaperonopathology. Acessed Feb 21, 2017.

20. Polverino F, Seys LJ, Bracke KR, Owen CA (2016) B Cells in Chronic Obstructive Pulmonary Disease: Moving to Center Stage. Am Physiol Lung Cell Mol Physiol 311: L687-L695.

21. Ospelt C, Camici GG, Engler A, Kolling C, Vogetseder A et al.(2014) Smoking induces Transcription of the Heat Shock Protein System in the Joints. Ann Rheum Dis 73: 1423-1426.
22. Khandia R, Munjal AK, Iqbal HMN, Dhama K (2017) Proteínas de Choque Térmico: Terapêuticas Perspectivas em Distúrbios Inflamatórios. Recente Pat Inflamm Allergy Drug Discov 10: 94-104.

23. Gołda R, Przybylski G, Jóźwicki W, Wyszomirska M (2012) Circulating Immune Complexes, Heat Shock Proteins in the Serum of Smoking Allergy Sufferers--Preliminary Results. Przegl Lek 69: 737-739.

24. de Moura CS, Lollo PC, Morato PN, Carneiro EM, Amaya-Farfan J (2013) Whey Protein Hydrolysate Enhances the Exercise-Induced Heat Shock Protein (HSP70) RESPOnse in Rats. Food Chem 136: 1350-1357.

25. Mayer MP (2013) Hsp70 Chaperone Dynamics and Molecular Mechanism. Trends Biochem Sci 38: 507-514. 